\title{
Research on Learners and Teachers of Mathematics and Science: Forerunners to a Focus on Teacher Educator Professional Growth
}

\author{
Konrad Krainer ${ }^{1} \cdot$ Ruhama Even $^{2} \cdot$ Meredith Park Rogers $^{3} \cdot$ Amanda Berry $^{4}$
}

Received: 30 April 2021 / Accepted: 30 April 2021/ Published online: 30 June 2021

(C) The Author(s) 2021

\begin{abstract}
This introductory paper first reflects the genesis of research in mathematics and science teacher education. The analyses show a movement from foci of research in mathematics and science education from students to teachers, and then to teacher educators. Next, an overview of research in mathematics and science teacher education and its development is provided, including teacher educators' growth. This is followed by a comparative look at the seven papers in this special issue through three lenses, focusing on who the teacher educators in these papers are, the practices which are the focus for development, and the contexts in which the professional growth is situated. The seven papers not only exemplify how teacher educators might critically and systematically reflect on their own growth, educate new teacher educators, and do corresponding research, but also demonstrate the considerable progress the research community has made with respect to the professional growth of mathematics and science teacher educators in the last decade. Finally, challenges and questions are raised, in particular in relation to raising the quality and quantity of proficient teacher educators in order to strengthen teacher education research, and to have enough human resources to offer more and better professional development opportunities and to support schools.
\end{abstract}

Keywords Collaboration - Context $\cdot$ Mathematics and science teacher educator $\cdot$ Practices $\cdot$ Professional growth

Konrad Krainer

konrad.krainer@aau.at

Meredith Park Rogers

mparkrog@indiana.edu

Extended author information available on the last page of the article 
The term "teacher educator" commonly refers to both those who educate prospective teachers and those who educate practicing teachers, that is, those who initiate, guide, and support teacher learning across the lifespan (e.g. Even, 2008; Krainer \& Llinares, 2010). A few researchers have tried to identify a possible trajectory for developing a teacher educator's professional knowledge base (Abell et al., 2009) or have described what that knowledge base should be comprised of and what practices teacher educators need to learn and develop (e.g. Berry \& van Driel, 2013; Even, 2005, 2008; Kelchtermans et al., 2017). Despite these efforts, there continues to be little research available on the professional growth of mathematics and science teacher educators. Therefore, the purpose of this special issue is to bring to light how researchers are working within and across the science and mathematics education communities to enhance teacher education by discussing important aspects regarding the professional growth of mathematics and science teacher educators. More specifically, what frameworks for professional growth are guiding our ideas about how to study teacher educators' learning and development, what models or programmatic experiences appear to be working well, and what common practices are occurring (perhaps even jointly) in science and mathematics education with respect to professional growth of teacher educators? Also, needing consideration is what methodological approaches can best serve our collective inquiry into this area of research? These and other questions related to understanding how mathematics and science teacher educators develop their beliefs and competencies for teaching teachers, as well as how these educators are learning to grow their own practice, were encouraged for submission to this issue in the open call we published. To ensure prospective and practicing teachers are receiving quality educational experiences in their learning of how to teach science and mathematics, much research is still needed into the knowledge and practice of those educating teachers in these disciplines. This issue seeks to address this goal.

In the following, we sketch first the movement from foci of research in mathematics and science education from students to teachers, and then to teacher educators. In the second section, we present an overview of research in mathematics and science teacher education and its development, including the question of teacher educators' growth. The third section looks at the seven papers through three lenses and at interconnections to the considerations in the former sections. Finally, the fourth section reflects on the process of selecting manuscripts for this special issue and stresses the importance of the theme of scaling up programs and studies regarding teacher educators' growth.

\section{Research on Students, Teachers, and Teacher Educators}

\section{Research on Students, Teachers, and Teacher Educators: What Emerged First?}

It is rather unimaginable that a Special Issue on "Science and Mathematics Teacher Educators and their Professional Growth" would have been published in the 1980s or earlier. One reason is that at that time, mathematics and science education research were still in their infancy, with foci on content, curriculum, applications, history, and on the learning of mathematics and science students. Until about 1990, even the focus of research on teachers' growth was rare; mathematics and science teacher education was mainly a field of practice. Papers often presented "success stories," not necessarily 
being theory-grounded and evidence-based. The field was searching for a common ground of research and teacher education (Cooney, 1994).

Reports about teacher educators' learning were to a large extent confined to short notes at the end of studies about teachers (e.g. Krainer, 2008, reflecting on the situation in mathematics education in the late 1990s). General insights into the complexity of teacher educators' work were provided by Ducharme (1993) and Korthagen (2000). In action research, the distinction between the "research" role of "insider practitioners" (e.g. teachers, investigating their own teaching) and the "research" role of "outsiders" (e.g. teacher educators, investigating the problems of facilitating teachers' reflective capacities or teacher educators" own learning) leads to the terms "first order" and "second order of action research" (e.g. Elliott, 1991, pp. 13, 26-27). Early examples in science teacher education were Munby and Russell (1994), who reflected on the development of their understanding of learning to teach in a Canadian physics teacher education class; also, Smith (2000) who studied the development of her pedagogical content knowledge as a primary science teacher educator. In mathematics teacher education, two of the first systematic self-studies of teacher educators' learning were written by Halai (1998) and Tzur (2001), who reflected on their own becoming mathematics teacher educators in Pakistan and Israel (respectively). At about the same time, pioneering research on structured professional education and development opportunities for teacher educators of practicing teachers occurred within the Developing Mathematical Ideas project (DMI) (Davenport \& Ebby, 2000) and the QUASAR project Stein et al. (1999) in the United States and the MANOR project in Israel (Even, 1999a, b).

It appears that-regarding the research focus on social entities, like students, teachers, and teacher educators - a first wave was research on students, later followed by research on teachers, and then by research on teacher educators. Similar observations regarding trends in mathematics education stem from Sfard (2005), Jaworski (2008), and Beswick (2020). This movement in the foci of research is further exemplified in the following.

In mathematics education, for example, the first international research journals were launched in 1968 (Educational Studies in Mathematics) and 1970 (Journal for Research in Mathematics Education), but the first research journal focusing on teacher education was published in 1998 (Journal of Mathematics Teacher Education, JMTE), about 30 years later. So far (2021), no research journal focusing on mathematics teacher educators' growth has been launched. A highly influential document, not only in North America but also all over the world was the "Curriculum and Evaluation Standards for School Mathematics" by the National Council of Teachers of Mathematics (NCTM, 1989), followed by a series of further books aiming at establishing a broad framework to guide reform in school mathematics. The NCTM activities fostered the forming of the Association of Mathematics Teacher Educators (AMTE) in 1991, which lead, among others, to a joint online journal (Mathematics Teacher Educator, MTE) in 2014.

The emergence of international handbooks shows a similar movement: the first International Handbook of Mathematics Education (Bishop et al., 1996) was published in the 1990s, whereas the first International Handbook of Mathematics Teacher Education appeared twelve years later (Wood et al., 2008). It was highly innovative at that time that this handbook dedicated one of its four volumes to "The Mathematics Teacher Educator as a Developing Professional” (Jaworski \& Wood, 2008). Similarly, 
the first large international comparative student assessment regarding mathematics and science teaching was started in 1995 (TIMSS), followed in 2000 by further studies for various subjects (PISA, PIRLS, etc.), but a parallel international comparative study on mathematics teachers followed in 2008 (TEDS-M). Again, so far, no such quantitative international study on mathematics teacher educators has been conducted. However, there is an increasing interest in self-studies in mathematics teacher education (e.g. Alderton, 2008; Schuck \& Brandenburg, 2020).

Similar to the field of mathematics education, much of the research in science education began with a focus on student learning. The preeminent journal Science Education (established 1916) focused much of its early research on how students learn and student conceptions about foundational science ideas. Since then, a focus on student learning has continued to have a strong presence in other leading journals in the field such as the International Journal of Science Education (established 1987; formerly the European Journal of Science Education (1979-1986)). The move to looking at the relationship between teaching and learning, and thus the learning of teachers, became a focus for publications in science education in the early 1960s. This was mainly due to K-12 curricular reforms in the United States as a result of the launch of Sputnik and the shadow it casted on the limited state of science and technology advancements in the United States at the time (Dickinson, 2007). It was during this time period that the Journal of Research on Science Teaching (established 1963) emerged and today still is one of the leading journals in the field sharing research on the relationship between teaching and learning of science, and science teacher learning in all contexts (preservice, inservice, informal, etc.) Additionally, in the late 1980s, the Association for Science Teacher Education (at that time referred to as the Association for the Education of Teachers of Science) launched the Journal of Science Teacher Education (established 1989). This journal focuses on the dissemination of research that pertains specifically to ways of improving science teaching in the context of teacher preparation programs, professional development, university/college settings, and overall teacher recruitment and retention in science education. It was not until much later, however, a focus on science teacher education began to gain traction in the field of science education. Since the mid-2000s, there has been a steady increase in the number of science education scholars engaging in self-study research, including the publication of two books devoted specifically to the topic (Bullock \& Russell, 2012; Buck \& Akerson, 2016).

This shows that, as a tendency, research on students emerged first, then followed by research on teachers, and only more recently a focus on teacher educators. We might regard this as a wavelike further development of research foci, where one focus leads to an additional focus, whereby the earlier foci continue to be important, again and again influencing the new foci.

\section{What Are the Reasons for this Wavelike Further Development of Research Foci?}

Why did research on students emerge first, then followed by research on teachers, and then by research on teacher educators? One main factor is surely the fact that the overall goal of mathematics and science teaching is students' learning, being the main output of the education system. Of course, international comparisons focusing on students' achievement (and beliefs, motivation, etc.) make differences among countries apparent. 
In turn, this generates interest by policy and science to elaborate reasons for the differences, in particular for countries not performing as assumed. It is evident that teachers (among other factors, see e.g. Hattie, 2008) have a strong impact on students' learning. This enforces plans to improve teachers' practice, knowledge, beliefs, reflections, etc. Thus, teacher education and relevant research become more prominent. Consequently, it can be assumed that the success of teacher education depends (among other factors, see e.g., Blömeke et al., 2008; Tatto et al., 2010) on teacher educators' practice, knowledge, beliefs, reflections, etc.

A second main factor for having research on students emerged first is complexity. In research related to students' knowledge, beliefs, learning, etc., the researcher-in general - is not part of an intervention, for example, teaching the student (and also investigating the impact). Usually, the researcher has a kind of distance to the investigated domain and collects data (audio- and/or video recording, interviews, measurements, observations, etc.). The main goal is to better understand a specific aspect of students' knowledge, beliefs, learning, etc.; the researcher is not responsible for students' status or progress (regarding knowledge, beliefs, learning, etc.). Thus, the research design has a clear distinction between the researcher and the researched. This has the advantage of distance and a higher degree of objectivity. However, it might miss the advantage of nearness (e.g., having deeper knowledge of students' thinking, of the learning context, other influences researchers might have not in their focus).

This traditional distinction between the researcher and the researched becomes blurred when it comes to research on teachers. Of course, there is research related to teachers' knowledge, beliefs, learning, etc., where the researcher is not part of an intervention. However, when the focus shifts from teachers to teacher education in the sense of an "interaction process (embedded in a social, organizational, cultural, ... context), mainly between teacher educators and (student) teachers" (Krainer et al., 1999a, b), then, the researcher is more or less involved. Not very complex kinds of involvement are research on other colleagues' teacher education initiative (course, program, etc.) or research on teachers who autonomously collaborate in an action research project (eventually facilitated by the teacher educator writing or co-writing the research paper). However, at the latest, when the teacher educator has also the role of the researcher, the situation becomes complex. In this case, the advantage of nearness (e.g., having deeper knowledge about the teachers, a variety of data sources, the chance to get feedback on assumptions or results, etc.) is apparent. However, the direct involvement in the interaction process means lacking distance and decreases objectivity. To a good part, the complexity has to do with the double goal and role of understanding and improving teachers' learning (research vs. teacher education). This needs a certain balance between nearness and distance and a high quality of reflection on advantages and disadvantages of nearness and distance. Teacher education is a kind of intervention into teachers' and teacher educators' interaction process; thus, research has the form of "intervention research" (e.g., Krainer, 2003).

A further step towards complexity is research on teacher educators. If these teacher educators are teachers in the sense of becoming future teacher educators, the situation is not very different to teacher education with respect to experienced teachers. For example, when the research focuses on colleagues working in the same institutional context or even department, striking a balance between nearness and distance becomes an even more delicate issue. And when teacher educators investigate their own learning 
as teacher educators, the "self" comes into play, making the nearness stronger and the distance lower, with all its advantages and disadvantages. Here, the interplay between understanding and improving one's own situation and profession growth becomes even closer. In principle, self-studies are a kind of "action research" (e.g. Altrichter \& Posch, 2009) as a special case of "intervention research." The difference between teachers' and teacher educators' action research lies, in general, in teacher educators' deeper knowledge in theoretical and methodological issues. However, the first principle for scientific work by Richard Feynman (1987), winner of the Nobel Prize in Physics, is the same for teachers and teacher educators: "you must not fool yourself."

With this attitude of mind, and a good basis regarding theory and methodology, investigating the self is of upmost importance, both for the individual researchers and the scientific field as a whole. It helps through understanding teacher educators' and researchers' own practice to improve their practice and scientific knowledge at the same time. An ideal balance of nearness and distance could be regarded as follows: the nearness of a self-study generates the advantage of having access to manifold data around one's own practice, of having the chance to deeply reflect individually or with "critical friends," and thus being able to go deeper into one case, considering the rich context. In contrast to traditional research, where "generalization" is a prominent goal, here "particularization" (Krainer, 2003, referring to Heintel, 1988) is a demanding goal, maybe, finding the "general" in the "particular." Self-studies are a rich methodology to focus on the particular and to face the challenge of generating knowledge (e.g., Kitchen et al., 2020), both interesting for the individual and the scientific community. In system theory (e.g., Willke, 2005), intervention is regarded as a specific chance to understand. For example, it is argued that through trying to bring about change in a social system, we can experience and observe phenomena (rules, resistances, tensions, etc.) who remain usually hidden when researchers are not intervening into the field.

Summing up, this shows that distance and nearness of the researcher to the researched both have advantages and disadvantages; none of those is superior or better than the other. In order to further promote the scientific field, we need both, considering that different research contexts and questions acquire different theoretical and methodological approaches. A "gold standard" in one case might be an inappropriate way in another case. It is about having a good rational for the intended and implemented research.

In the following, we focus on the status and the further development of research of teacher education in order to prepare our look on the status of research on teacher educators' professional growth. This will be done in two steps: first, major surveys in research of mathematics teacher education are summarized; then, corresponding results from research of science teacher education are sketched.

\section{The Status of Research in Mathematics and Science Teacher Education}

\section{What Do We Know About the Status of Research in Mathematics Teacher Education and Its Development?}

Cooney (1994, p. 631) stressed that "as a profession we have just begun to recognize the significance of conceptual orientations for guiding research on teacher education". 
In 1998, JMTE as the first international research journal focusing on mathematics teacher education was a milestone for the field. Parallel to the start of this journal, also numerous books and articles were published (see e.g., Loucks-Horsley et al., 1998; Jaworski et al., 1999; Krainer et al., 1999a, b; Lin \& Cooney, 2001; Peter-Koop et al., 2003; Strässer et al., 2004). Also, works on the first International Handbook of Handbook of Mathematics Teacher Education (Wood et al., 2008) and on the first ICMI study on teacher education, the 15th ICMI Study on "The Professional Education and Development of Teachers of Mathematics" (Even \& Ball, 2009), were launched at that time.

In 2004, a survey on research of mathematics teacher education from 1999 to 2003 was presented at ICME-10 (Adler et al., 2005). The survey worked out four claims (shortened):

Claim 1: Small-scale qualitative research predominates. This kind of research (studies that focus on less than 20 teachers, including many case studies on single teachers) is highly important and also somewhat natural since most teacher education activities deal with a restricted number of participants (which minimizes complexity and allows going deeper in research). Nevertheless, more comparative and large-scale studies in teacher education would enrich the field.

Claim 2: Most teacher education research is conducted by teacher educators studying the teachers with whom they are working. Most mathematics teacher education programs are reported on by those who designed and implemented them. This kind of research (including studies based on action research) is highly important, too. In addition, it makes sense to combine teacher educators' practice (teaching) with research interests. Nevertheless, more studies where externals investigate the effects of teacher education would extend the knowledge of the field.

Claim 3: Research in countries where English is the national language dominates the literature. About three-fourths of journal papers (JMTE and JRME) stem from such countries. In PME proceedings, the situation is with a percentage of $43 \%$ less stark, but nevertheless prevalent.

Claim 4: Some questions have been studied, not exhaustively, but extensively, while other important questions remain unexamined. For example, the authors indicated many teacher studies on professional communities (supporting Claim 1) and many articles that involve efforts showing that particular programs of teacher education 'work' (supporting Claim 2). Fewer studies were, for example, carried out in teacher learning outside of "reform contexts" or about programs aiming at spreading to multiple sites (scaling up).

Gellert et al. (2012) conducted a similar survey for the period 2005-2010, focusing on research methods, methodology, and techniques in studies on mathematics teacher education and building on the above sketched survey (Adler et al., 2005). They report that Claim 1 is still legitimate (e.g. $89 \%$ of studies involve less than 100 teachers), the same holds for Claim 3 (e.g. $70 \%$ of papers with single-nation authors came from English-speaking contexts). Regarding methodology, the authors claim that in the observed period (the late 2000s), 
new perspectives, methodologies, and techniques have been established. For example, they show a slight increase in the number of studies that combined qualitative and quantitative methods at the expense of studies using qualitative methods only; although interviews formed the dominant category of techniques in the qualitative and mixed method studies, new techniques were carried out (e.g., involving narratives /stories, videos, and concept maps). As an example from the "politicized periphery," the authors report the development of Participatory Action Research in Latin America. They emphasize that the research-actionreflection-emancipation process is an important means for researchers in these contexts to make society and its institutions more democratic and egalitarian. To some extent, this supports the view that in specific (national, but surely also regional and local) contexts, action research is a powerful means both to understand and to improve, indicating again that Claim 2 cannot be regarded as a deficit, but as a mirror of necessities of teachers, teacher educators, and researchers. It also indicates - regarding Claim 4-that the general view (whether questions remain unexamined or were studied exhaustively) is one side of the coin - the other is the particular view (formed and influenced by the situated context).

A recent survey focusing on research on mathematics teachers working and learning in collaborative groups from 2018 to 2019 (Krainer \& Spreitzer, 2020) confirms Claims 1 and 2 (not looking at Claim 3 and Claim 4). In addition, the authors report some further observations, for example: (a) most research focuses on improvements and successes; (critical) reflections on researchers' (co-)learning-although focusing on collaboration - are rare; (b) only a few initiatives describe the context and relevant environments having a potential impact on the initiative; (c) most initiatives stress the importance of sharing reflections as a crucial factor for working with teachers and possibly other groups (a similar observation stems from a literature review of PME papers by Llinares and Krainer 2006).

Although such analytic views on a particular theme like collaborative groups show some white spots in research, finding seven high-quality papers on that theme within a two-year span only (2018-2019) is remarkable. This view is supported by the fact that the theme "Teachers of mathematics working and learning in collaborative groups" is the focus of a recent ICMI Study (International Program Committee for ICMI-25 Study, 2019; see also Robutti et al., 2016) whose corresponding proceedings (Borko \& Potari, 2020) demonstrate a diverse and rich coverage of this theme. Similar progress is mirrored, for example, by the volume "The Impact of University Teacher Education Programs on Teacher Change and Mathematics Teaching Practice" of ZDM (49/2, An \& Chapman, 2017).

JMTE continued to be the key international journal in mathematics teacher education, producing up to six issues per year and several special issues (e.g., "Video as a Catalyst for Mathematics Teachers' Professional Growth", 2017), succeeding 2019 in being accepted in the Web of Science's Social Sciences Citation Index).

In 2020, the second edition of the International Handbook of Mathematics Teacher Education Chapman et al. (2020) was launched. It builds on and extends the first edition of this handbook (Wood et al., 2008), again consisting of four volumes, the fourth one focusing on "The Mathematics Teacher Educator as a Developing Professional" (Beswick \& Chapman, 2020). 


\section{What Do We Know about the Status of Research in Science Teacher Education and Its Development?}

Similar to research in mathematics education, since its beginnings in the $1960 \mathrm{~s}$ as a distinct field, science education research has evolved from a focus largely concerned with students and their learning, to include teachers and their teaching. As research in science education developed through the 1990s, a focus on students' science conceptions remained strong, but the field also expanded to include studies of science teachers' content knowledge (CK) and their pedagogical content knowledge (PCK) (de Jong, 2007). This interest in science teachers' PCK was very much influenced by the pioneering work of Lee Shulman and colleagues who introduced the construct of pedagogical content knowledge (PCK) in the middle of 1980s to acknowledge and highlight a specialized form of professional knowledge possessed by teachers that sets them aside from other professionals in other fields (Shulman, 1986). Shulman's model of PCK has had a profound and far-reaching impact on research into teachers' knowledge, particularly in science education. The idea of PCK was rapidly taken up, explored, adopted, and adapted by science education researchers in the field, including most recently, two international summits $(2012,2016)$ that further elaborated and expanded a model of PCK to result in the Refined Consensus Model (RCM) of PCK for teaching science (Carlson et al., 2019).

Alongside the growing interest in science teachers, an additional strand of research emerged in the 1990s, focusing on science teacher educators. This new area arose partly from teacher educators' own motivations to learn more about their own practices, and partly in response to the growing interest in the knowledge base of teacher education (Berry \& Loughran, 2002). Following the tradition of teacher as researcher, many science teacher educators have engaged in self-study research because that work mirrors their own concerns for student learning in science, for example, identifying and confronting alternative conceptions, and creating active and responsible learners. (For an early example, see Russell, 1995). In 1997, the (US based) Association for Education of Teachers in Science published a position statement on Professional Knowledge Standards for Science Teacher Educators (JSTE, Lederman et al., 1997) in an attempt to outline the knowledge and skills required by science teacher educators. However, Abell et al. (2009) recommended this set of standards needed reconsideration to meet the demands and reforms of science teacher education and suggested a new standard called "Knowledge for Teaching Preservice Teachers." The focus of this standard is on teacher educators in their doctoral programs and the experiences they need to grow professionally in their knowledge and practice for teaching teachers.

\section{What Do We Know about the Status of Research on Teacher Educators' Professional Growth?}

Since the publication of the special volume "The Mathematics Teacher Educator as a Developing Professional" (Jaworski \& Wood, 2008) in the first international handbook of mathematics teacher education, and the 15th ICMI Study Volume on "The Professional Education and Development of Teachers of Mathematics" (Even \& Ball, 2009), 
which suggested in its concluding chapter (Ball \& Even, 2009) that the international community should focus and build on collective capacity on the issue of identification and development of teacher developers, several efforts have been taken to push research on "educating the mathematics teacher educators" forward. For example, a themed issue of ZDM (Jaworski \& Huang, 2014) that centered on the professional development of mathematics teacher educators who work in the field of teaching development with practicing teachers. Nearly at the same time, a conference focused on "Educating the educators: international approaches to scaling-up professional development in mathematics and science education" (Maaß et al., 2015).

Beswick and Goos (2008) published an editorial named "Mathematics teacher educator knowledge: What do we know and where to from here?" in a JMTE issue where they review the papers of this issue, taking into account a wider range of literature. Their abstract stresses that "the knowledge that mathematics teacher educators need has attracted limited but increasing attention in recent years." Concluding, they state that research into the knowledge of mathematics teacher educators "is beginning to consider finer grained issues and contexts in a way that is analogous to other areas of mathematics education that have shifted progressively from broad concepts to more nuanced issues" (p. 424), indicating several new areas of research. In her introduction to the fourth volume, "Mathematics teacher educators as developing professionals" of the second international handbook of mathematics teacher education, Beswick (2020) provides an outline of developments in research on mathematics teacher educators over the period since the first edition of the handbook. Although concluding that there has been manifold progress in the field's understanding of mathematics teacher educators, she regards this understanding "still in its infancy."

Similarly, research in the field of science teacher educators' professional growth is still mainly in a nascent stage. Much of the work in this field has focused on the efforts of individual science teacher educators to better understand the development of their knowledge for teaching prospective science teachers, typically in the context of transitioning from school-based teacher to teacher educator (e.g., Berry, 2008; Bullock, 2012; Garbett, 2012), or from scientist to science teacher educator (e.g., Santau, 2012). The nature of professional growth revealed through these studies is usually reported in terms of learning to move beyond "technical rationality" (Schön, 1983) to more nuanced and productive understandings of professional knowledge. For example, Berry (2008) came to conceptualize her professional growth as a biology teacher educator in terms of series of "tensions of practice" to be managed (as opposed to problems to be solved), while Bullock, a physics teacher educator articulated his professional growth in terms of a distinct pedagogy of teacher education (Bullock, 2012). In their conclusion to their Handbook chapter, "Research on Science Teacher Knowledge" (2014), van Driel, Berry and Meirnik noted the lack of attention paid to the role and expertise of science teacher educators and encouraged those working in the field to document the expertise of this group, including its development in the different contexts in science teacher educators' work.

\section{Introducing the Papers in This Special Issue}

This special issue on "Science and Mathematics Teacher Educators and their Professional Growth" includes - in addition to this introductory paper and an epilogue- 
seven research papers. In the following, drawing on Even $(2008,2014)$ and Krainer (2015), we employ three lenses to introduce the papers: (1) Who are the teacher educators in this special issue? (2) What practices of teacher educators are the focus for development? (3) In what contexts the professional growth of teacher educators is situated?

\section{Who Are the Teacher Educators in This Special Issue?}

Traditionally, the term "teacher educator" has been reserved for university- and collegebased educators who teach prospective teachers in formal teacher education programs. However, in this special issue, we embrace a more contemporary approach, which includes in the group of people entitled teacher educators all those whose role is to educate teachers - prospective or practicing - that is, those who initiate, guide, and support teacher learning across the lifespan (Ball \& Even, 2009; Beswick \& Chapman, 2020; Beswick \& Goos, 2008; Even, 2008, 2014; Krainer \& Llinares, 2010). Thus, a large group of people, who commonly are not named teacher educators, are perceived as such because their roles are to educate teachers. These include, for instance, mentors, facilitators, teacher leaders, and coaches.

In line with this extended view, the teacher educators in the collection of papers in this issue are as follows: university-based teacher educators who educate prospective teachers (Hanuscin et al., 2021; Lloyd et al., 2021; Superfine \& Pitvorec, 2021; Weinberg et al., 2021), and practicing teachers (Triantafillou et al., 2021; Weinberg et al., 2021), as well as practice-based teacher-educators working with practicing teachers (Borko et al., 2021; Venkat \& Askew, 2021). Reflecting the current absence of an agreed-upon name for practice-based teacher educators, the terms used for these people by the authors in this special issue are Teacher-Leaders (Borko et al., 2021) and Mathematics Subject Advisors (Venkat \& Askew, 2021).

\section{What Practices of Teacher Educators Are the Focus for Development?}

The professional education and development of teacher educators is an emerging field of research. Current scholarly work tends to focus on knowledge: what do teacher educators need to know? This line of research provides useful models and frameworks for conceptualizing teacher educators' knowledge (e.g., Berry, 2008; Beswick \& Chapman, 2020; Beswick \& Goos, 2008; Brandenburg, 2008; Jaworski \& Huang, 2014). Yet, whereas knowledge is, of course, important, the work of teacher educators, just like the work of schoolteachers is something one does, not just knows.

The field of teacher education has begun in recent years to undergo "a major shift — a turn away from a predominant focus on specifying the necessary knowledge for teaching towards specifying teaching practices that entail knowledge and doing" (McDonald et al., 2013). A growing strand of research on teacher education has attempted to focus teacher education on "core" or "high leverage" practices of teaching (e.g., Forzani, 2014; Grossman, 2018; Windschitl et al., 2012). These include, for example, facilitating classroom discussions, eliciting student thinking, and maintaining classroom norms. Correspondingly, in the case of the professional growth of teacher educators, there is a need to focus, in addition to knowledge, on practices of teacher educators and on the integration between knowledge and practice (Dinkelman et al., 2006; Even, 2008). 
The papers in this special issue contribute important information regarding practices of teacher educators that were the focus of development. Selected practices include promoting discussions in mathematics courses for prospective teachers (Superfine \& Pitvorec, 2021), adapting the design of workshops in response to specific teachers' needs and goals (Borko et al., 2021), supporting teachers' inquiry into teaching/ learning mathematics and science (Triantafillou et al., 2021), adapting existing approaches to new audiences (Hanuscin et al., 2021), connecting university coursework to prospective teachers' field experiences (Lloyd et al., 2021), supporting teachers in implementing an intervention developed by academic faculty (Venkat \& Askew, 2021), and working in a university-based teacher educators' Community of Practice (Weinberg et al., 2021).

These, and other practices of teacher educators described in these papers, could serve as a useful starting point for discussing what "core" or "high leverage" practices of educating teachers might be. Moreover, the difficulties that mathematics teacher educators encountered when working with cross-disciplinary groups of practicing mathematics and science teachers (Triantafillou et al., 2021) suggest that there is also the need to investigate whether there are different core practices of educating teachers for different sub-communities of the extended community of mathematics and science teacher educators.

\section{In What Contexts Is the Professional Growth of Teacher Educators Situated?}

Traditionally, teacher educators have no formal preparation for their work, and their professional growth receives little institutional and professional support. This missing component in the efforts to improve the professional education and development of teacher educators has been recognized in recent years by the international communities of mathematics and science educators (e.g., Berry, 2008; Even, 2008; Ball \& Even, 2009; Bullock \& Russell, 2012; Jaworski \& Huang, 2014) and pioneering works in structuring the professional preparation and development of teacher educators have emerged in different countries (e.g., Berry, 2016; Even, 1999a, 2005; Jaworski, 2008; Loughran, 2014; McGatha \& Rigelman, 2017; Zehetmeier et al., 2017). Yet, there continues to be little research available on how to support the professional growth of mathematics and science teacher educators in their work with teachers and what learning experiences are useful for that.

The papers in this special issue describe a wide range of contexts in which the professional growth of teacher educators was situated, highlighting a variety of institutional and professional kinds of support. Reflecting the current state of the field of preparation and development of teacher educators, which in many countries is not part of a systematic institutionalized practice, most of the papers in this issue are situated in insightful and innovative, yet local, initiatives, that to a large extent are dependent on the particular individuals who initiate, design, lead, and operate them. An important contribution of this special issue is rooted in the detailed illustrations and thoughtful deliberations of the professional growth of teacher educators that belong to different groups.

Four of the papers in this issue focus on the professional growth of university-based teacher educators (Hanuscin et al., 2021; Superfine \& Pitvorec, 2021; Triantafillou et al., 2021; Weinberg et al., 2021), one paper centers on the professional growth of a 
mixed group of university- and practice-based teacher educators (Lloyd et al., 2021), and two on practice-based teacher educators (Borko et al., 2021; Venkat \& Askew, 2021). In contrast with the traditional approach to professional growth of teacher educators as a by-product of their work, the contexts in which the professional growth of teacher educators was situated in all papers involved structured, sometimes formal, professional learning opportunities. Below, we briefly mention these contexts.

The papers that focus on the professional growth of university-based teacher educators describe distinct professional learning models, developed and used at the authors' respective institutes. Superfine and Pitvorec's (2021) model involves collaborative creation and revision of community artifacts, namely lesson plans, by a university-based Community of Practice $(\mathrm{CoP})$, which was created to support novice mathematics teacher educators. Weinberg et al.'s (2021) professional learning model is also rooted in a university-based CoP, which is used as a safe space for STEM teacher educators to self-promote their multi-faceted identity (trans)formation. Hanuscin et al.'s (2021) professional learning model is institutionally sanctioned cross-disciplinary and collaborative initiative that involves structured shadowing of colleagues, created to support the professional growth of both novice and experienced science universitybased teacher educators. Finally, the model for professional learning opportunities in Triantafillou et al.'s (2021) study comprised meetings of university-based mathematics and science teacher educators with the goal of devising a common agenda for ways of supporting mathematics and science teacher collaboration.

All three papers that include a focus on the professional growth of practice-based teacher educators were rooted in a partnership between a university and schools. Each paper describes a professional learning model, developed and used at the authors' respective institutes. The context for Lloyd et al.'s (2021) study was intended for professional learning of both university- and practice-based teacher educators. Their professional learning model was rooted in a professional development school (PDS) partnership between a university and schools surrounding it, which involved weekly meetings of the PDS teacher educators about the work of the partnership, facilitated by the PDS Coordinator. Focusing on the professional growth of practice-based teacher educators, the professional learning models in Borko and colleagues' and Venkat and Askew's (2021) papers comprised formal sessions, with the goal of preparing and supporting practice-based teacher educators in conducting similar PD sessions for teachers.

\section{Conclusion}

As demonstrated earlier, the professional growth of mathematics and science teacher educators is an under-researched area. To address the need for quality educational experiences for mathematics and science teachers in their learning to teach or develop their teaching, much research is still needed into those educating teachers in these disciplines. This special issue on "Science and Mathematics Teacher Educators and their Professional Growth" seeks to address this goal.

The seven research papers included in this issue are the outcome of a rigorous review and selection process of 109 proposals of papers we received in response to the open call we widely disseminated. Out of the 109 proposals, about one-half of the first 
author's affiliations were from North America (53, with 49 from the US), about onefourth from Europe (25), and about one-fourth from all other continents: Asia (15), South America (7), Australia/Oceania (6), and Africa (3). More than one-half of the paper proposals (62) came from countries where English is the national language - in line with the above-mentioned claim 2 regarding the dominance of research in countries where English is the national language in the literature on mathematics and science teacher education (Adler et al., 2005; Gellert et al., 2012). This is reflected in the collection of papers in this issue.

Most of the paper proposals we received - about two-thirds (72)-focused on the professional growth of either mathematics or science teacher educators (47 and 25 , respectively). About one-third (37) of the proposals focused on both disciplines, either as two distinct disciplines (23) or as interconnected (14). This, again, is reflected in the collection of papers in this issue. With the growing interest in STEM education in general and in STEM integration in particular (e.g., Li et al., 2020) the collection of the papers in this issue provides important information regarding the complexity involved in the work of teacher educators who educate prospective and practicing teachers of STEM subjects.

The seven papers in this special issue showcase different approaches researchers used to study the professional growth of mathematics and science teacher educators. Overall, the collection of the papers provides insights into the current state of research about this issue. It presents innovative programs and provides the reader with noteworthy research results. This special issue demonstrates the considerable progress our research community has made with respect to the professional growth of mathematics and science teacher educators in the last decade.

It is a sign of maturity of a field of social research when it not only investigates the growth of others - in the field of education, in particular students and teachers - but also their own actions, in a systematic and theory-driven way. Teacher educators, involved in working with prospective and practicing teachers, need not only focus on teachers' growth, but also on their own growth, since their knowledge, beliefs and actions (etc.) influence also teachers' knowledge, beliefs, and actions (etc.). The fact that in many such research endeavors teacher educators and researchers overlap, increases the complexity of the social action, however, this is not a reason to avoid such a research; on the contrary, it is an additional reason to increase our efforts.

Due to its complexity, the issue of teacher educators' professional growth has and will continue to have dozens of white spots regarding research. Of course, research on teachers' professional growth contributes new perspectives and ways to research related to teacher educators' growth. However, when even in teacher education research, an explicit need for scaling up programs and studies in the context of teacher education is expressed (e.g. Adler et al., 2005; Maaß et al., 2019), then the white spots regarding teacher educators' growth will even be larger.

This special issue provides good examples where teacher educators critically and systematically reflect on their own growth, educate new teacher educators, and do corresponding research. However, questions like these still remain: How can we extend the number of proficient teacher educators in order to have enough human resources to offer more and better professional development opportunities and to support schools (their mathematics and science departments, etc.) to foster their focus on improving mathematics and science teaching? And what can we do to support these teacher educators in doing proper research related to their work as teacher educators? 
Funding Open access funding provided by University of Klagenfurt.

Open Access This article is licensed under a Creative Commons Attribution 4.0 International License, which permits use, sharing, adaptation, distribution and reproduction in any medium or format, as long as you give appropriate credit to the original author(s) and the source, provide a link to the Creative Commons licence, and indicate if changes were made. The images or other third party material in this article are included in the article's Creative Commons licence, unless indicated otherwise in a credit line to the material. If material is not included in the article's Creative Commons licence and your intended use is not permitted by statutory regulation or exceeds the permitted use, you will need to obtain permission directly from the copyright holder. To view a copy of this licence, visit http://creativecommons.org/licenses/by/4.0/.

\section{References}

Abell, S. K., Park Rogers, M. A., Hanuscin, D., Lee, M. H., \& Gagnon, M. J. (2009). Preparing the next generation of science teacher educators: A model for developing PCK for teaching science teachers. Journal of Science Teacher Education, 20(1), 77-93. https://doi.org/10.1007/s10972-008-9115-6.

Adler, J., Ball, D., Krainer, K., Lin, F.-L., \& Novotna, J. (2005). Reflections on an emerging field: Researching mathematics teacher education. Educational Studies in Mathematics, 60(3), 359-381. https://doi.org/10.1007/s10649-005-5072-6.

Alderton, J. (2008). Exploring self-study to improve my practice as a mathematics teacher educator. Studying Teacher Education: A Journal of Self-Study of Teacher Education Practices, 4(2), 95-104. https://doi. org/10.1080/17425960802433587.

Altrichter, H., \& Posch, P. (2009). Action research, professional development and systemic reform. In S. Noffke \& B. Somekh (Eds.), The SAGE handbook of educational action research (pp. 213-225). SAGE Publications.

An, S. \& Chapman, O. (Eds.). (2017). The impact of university teacher education programs on teacher change and mathematics teaching practice. ZDM - The International Journal on Mathematics Education, 49(2). https://link.springer.com/journal/11858/volumes-and-issues/49-2.

Ball, D. L., \& Even, R. (2009). Strengthening practice in and research on the professional education and development of teachers of mathematics: Next steps. In R. Even \& D. L. Ball (Eds.), The professional education and development of teachers of mathematics: The 15th ICMI study (pp. 255-260). Springer.

Berry, A. (2008). Tensions in teaching about teaching: Understanding practice as a teacher educator. Springer. https://doi.org/10.1007/1-4020-5993-0.

Berry, A. (2016). Teacher educators' professional learning: A necessary case of 'on your own'? In B. de Wever, R. Vanderlinde, M. Tuytens, \& A. Aelsterman (Eds.), Professional learning in education: Challenges for teacher educators, teachers and student teachers (pp. 39-56). Academia Press.

Berry, A., \& Loughran, J. J. (2002). Developing an understanding of learning to teach in teacher education. In J. Loughran \& T. Russell (Eds.), Improving teacher education practices through self-study (pp. 13-29). Routledge Falmer.

Berry, A., \& van Driel, J. H. (2013). Teaching about teaching science: Aims, strategies and backgrounds of science teacher educators. Journal of Teacher Education, 64(2), 117-128. https://doi.org/10.1177/ 0022487112466266.

Beswick, K. (2020). Mathematics teacher educators as developing professionals. An introduction. In K. Beswick \& O. Chapman (Eds.), International handbook of mathematics teacher education (Vol. 4, 2nd ed., pp. 1-11). Brill. https://doi.org/10.1163/9789004424210.

Beswick, K., \& Chapman, O. (Eds.). (2020). International handbook of mathematics teacher education (2nd edition), volume 4: The mathematics teacher educators as developing professionals. Brill. https://doi.org/ $10.1163 / 9789004424210$.

Beswick, K., \& Goos, M. (2008). Mathematics teacher educator knowledge: What do we know and where to from here? Journal of Mathematics Teacher Education, 21(5), 417-427. https://doi.org/10.1007/s10857018-9416-4.

Bishop, A. J., Clements, M. A., Keitel, C., Kilpatrick, J., \& Laborde, C. (Eds.). (1996). International handbook of mathematics education. Kluwer.

Blömeke, S., Felbrich, A., Müller, C., Kaiser, G., \& Lehmann, R. (2008). Effectiveness of teacher education: State of research, measurement issues and consequences for future teachers. ZDM - The International Journal on Mathematics Education, 40(5), 719-734. https://doi.org/10.1007/s11858-008-0096-x. 
Borko, H., \& Potari, D. (2020). Teachers of mathematics working and learning in collaborative groups. Proceedings of the ICMI-15 Study Conference. https:/www.mathunion.org/icmi/conferences/icmi-studyconferences

Borko, H., Carlson, J., Deutscher, R., Boles, K. L., Delaney, V. L., Fong, A. B., Jarry-Shore, A., Malamut, J., Million, S., Mozenter, S., \& Villa III, A. M. (2021). Learning to lead: An approach to mathematics teacher leader development. International Journal of Science and Mathematics Education, 19(Suppl. 1). https://doi.org/10.1007/s10763-021-10157-2.

Brandenburg, R. (2008). Powerful pedagogy. Self-study of a teacher educator's practice. Springer.

Buck, G. A., \& Akerson, V. L. (Eds.). (2016). Enhancing professional knowledge of pre-service science teacher education by self-study research: Turning a critical eye on our practice. Springer.

Bullock, S. (2012). Learning to teach physics teachers: Developing a distinct pedagogy of teacher education. In S. M. Bullock \& T. Russell (Eds.), Self-studies of science teacher education practices (pp. 103-120). Springer.

Bullock, S. M., \& Russell, T. (Eds.). (2012). Self-studies of science teacher education practices. Springer.

Carlson, J., Daehler, K. R., Alonza, A. C., Barendsen, E., Berry, A., Borowski, A., Carpendale, J., Chan, K. K. H., Cooper, R., Friedrichsen, P., Gess-Newsome, J., Ineke, H.-R., Hume, A., Kirschner, S., Liepertz, S., Loughran, J., Mavhunga, E., Neumann, K., Nilsson, P., . . W Wilson, C. (2019). The refined consensus model of pedagogical content knowledge in science education. In A. Hume, R. Cooper, \& A. Borowski (Eds.), Repositioning pedagogical content knowledge in teachers' knowledge for teaching science (1st ed., pp. 39-56). Ginko Press \& Academia Press.

Chapman, O., Potari, D., Llinares, S., Llyod, G. M., \& Beswick, K. (Eds.). (2020). International handbook of mathematics teacher education (2nd edition). 4 volumes. Brill.

Cooney, T. (1994). Research and teacher education. In search of common ground developed. Journal for Research in Mathematics Education, 25(6), 608-636. https://doi.org/10.2307/749575.

Davenport, L. R., \& Ebby, A. (2000, April). Teacher leadership development in mathematics education: Stories of three apprentices. Paper presented at the annual meeting of American Educational Research Association, New Orleans, .

de Jong, O. (2007). Trends in western science curricula and science education research: A bird's eye view. Journal of Baltic Science Education, 6(1), 15-22. Retrieved from http://oaji.net/articles/2014/9871404286727.pdf.

Dickinson, P. (2007). Sputnik's Impact on America. NOVA. https://www.pbs.org/wgbh/nova/article/sputnikimpact-on-america/.

Dinkelman, T., Margolis, J., \& Sikkenga, K. (2006). From teacher to teacher educator: Reframing knowledge in practice. Studying Teacher Education, 2(2), 119-136. https://doi.org/10.1080/17425960600983155.

Ducharme, E. R. (1993). The lives of teacher educators: In their own words. New York, NY: Teachers' College Press. Education Committee of the EMS (2012). It is necessary that teachers are mathematically proficient, but is it sufficient? Solid findings in mathematics education on teacher knowledge. Newsletter of the European Mathematical Society, 83(March 2012), 46-50.

Elliott, J. (1991). Action research for educational change. Open University Press.

Even, R. (1999a). The development of teacher-leaders and in-service teacher educators. Journal of Mathematics Teacher Education, 2(1), 3-24. https://doi.org/10.1023/A:1009994819749.

Even, R. (1999b). Integrating academic and practical knowledge in a teacher leaders' development program. Educational Studies in Mathematics, 38(3), 235-252. https://doi.org/10.1023/A:1003665225190.

Even, R. (2005). Integrating knowledge and practice at MANOR in the development of providers of professional development for teachers. Journal of Mathematics Teacher Education, 8(4), 343-357. https://doi.org/10.1007/s10857-005-0855-3.

Even, R. (2008). Facing the challenge of educating educators to work with practicing mathematics teachers. In B. Jaworski \& T. Wood (Eds.), The international handbook of mathematics teacher education, volume 4: The mathematics teacher educator as a developing professional (pp. 57-73). Sense Publishers.

Even, R. (2014). Challenges associated with the professional development of didacticians. ZDM - The International Journal on Mathematics Education, 46(2), 329-333. https://doi.org/10.1007/s11858-0140573-3.

Even, R., \& Ball, D. L. (Eds.). (2009). The professional education and development of teachers of mathematics: The 15th ICMI Study. Springer https://link.springer.com/book/10.1007/978-0-387-09601-8.

Feynman, R. (1987). Sie belieben wohl zu scherzen, Mr. Feynman! [Surely You're Joking, Mr. Feynman!]. Piper.

Forzani, F. M. (2014). Understanding “core practices" and "practice-based" teacher education: Learning from the past. Journal of Teacher Education, 65(4), 357-368. https://doi.org/10.1177/0022487114533800. 
Garbett, D. (2012). The transformation from expert science teacher to science teacher educator. In S. M. Bullock \& T. Russell (Eds.), Self-studies of science teacher education practices (pp. 31-44.) Springer.

Gellert, U., Hernández, R. B., \& Chapman, O. (2012). Research methods in mathematics teacher education. In M. Clements, A. Bishop, C. Keitel, J. Kilpatrick, \& F. Leung (Eds.), Third international handbook of mathematics education (pp. 327-360). Springer. https://doi.org/10.1007/978-1-4614-4684-2_11.

Grossman, P. (Ed.). (2018). Teaching core practices in teacher education. Harvard University Press.

Halai, A. (1998). Mentor, mentee, and mathematics: A story of professional development. Journal of Mathematics Teacher Education, 1(3), 295-315. https://doi.org/10.1023/A:1009994102455.

Hanuscin, D., Donovan, D., Acevedo-Gutierrez, A., Borda, E., DeBari, S., Melton, J., Le, T., Morrison, W., \& Ronca, R. (2021). Supporting the professional development of teacher educators through shadowing. International Journal of Science and Mathematics Education, 19(Suppl. 1). https://doi.org/10.1007/ s10763-021-10154-5.

Hattie, J. (2008). Visible learning. A synthesis of over 800 meta-analyses relating to achievement. Routledge.

Heintel, P. (1988). Zum Wissenschaftsbegriff des IFF [The IFF's concept of science]. Österreichische Hochschulzeitung (Sonderdruck) Nr., 3, 7-10.

International Program Committee for ICMI-25 Study. (2019). Teachers of mathematics working and learning in collaborative groups. Discussion document. https://www.mathunion.org/fileadmin/ICMI/ICMI\% 20studies/ICMI\%20Study\%2025/190218\%20ICMI-25_To\%20Distribute_190304_edit.pdf

Jaworski, B. (2008). Development of the mathematics teacher educator and its relation to teaching development. In B. Jaworski \& T. Wood (Eds.), International handbook of mathematics teacher education (Vol. 4, pp. 177-199). Sense Publishers.

Jaworski, B., \& Huang, R. (2014). Teachers and didacticians: Key stakeholders in the processes of developing mathematics teaching. ZDM - The International Journal on Mathematics Education, 46(2), 173-188. https://doi.org/10.1007/s11858-014-0574-2.

Jaworski, B., \& Wood, T. (Eds.). (2008). International handbook of mathematics teacher education, volume 4: The mathematics teacher educator as a developing professional. Sense Publishers.

Jaworski, B., Wood, T., \& Dawson, S. (Eds.). (1999). Mathematics teacher education. Critical international perspectives. Falmer Press.

Kelchtermans, G., Smith, K., \& Vanderlinde, R. (2017). Towards an 'international forum for teacher educator development': An agenda for research and action. European Journal of Teacher Education, 41(1), 120134. https://doi.org/10.1080/02619768.2017.1372743.

Korthagen, F. (2000). Teachers educators: From neglected group to spearhead in the development of education. In G. M. Willems, J. Stakenborg, \& W. Veuglers (Eds.), Trends in Dutch teacher education (pp. 35-48). Garant.

Krainer, K. (2003). Teams, communities and networks. Editorial. Journal of Mathematics Teacher Education, 6(2), 93-105. https://doi.org/10.1023/A:1023918616310.

Krainer, K. (2008). Reflecting the development of a mathematics teacher educator and his discipline. In B. Jaworski \& T. Wood (Eds.), International handbook of mathematics teacher education, The mathematics teacher educator as a developing professional (Vol. 4, pp. 177-199). Sense Publishers.

Krainer, K. (2015). Reflections on the increasing relevance of large-scale professional development. ZDM The International Journal on Mathematics Education, 47(1), 143-151. https://doi.org/10.1007/s11858015-0674-7.

Krainer, K., \& Llinares, S. (2010). Mathematics teacher education. In P. Peterson, E. Baker, \& B. McGaw (Eds.), International encyclopedia of education (Vol. 7, pp. 702-705). Elsevier.

Krainer, K., \& Spreitzer, C. (2020). Collaborative groups in mathematics teacher education: Grasping the diversity of roles, identities and interactions. In H. Borko \& D. Potari (Eds.), Teachers of Mathematics Working and Learning in Collaborative Groups (pp. 23-36). National and Kapodistrian University of Athens. https://www.mathunion.org/icmi/conferences/icmi-study-conferences.

Krainer, K., Goffree, F., \& Berger, P. (Eds.). (1999a). On research in mathematics teacher education. European research in mathematics education I.III. Forschungsinstitut für Mathematikdidaktik.

Krainer, K., Goffree, F., \& Berger, P. (1999b). Preface. In K. Krainer, F. Goffree, \& P. Berger (Eds.), European research in mathematics education I.III. On research in mathematics teacher education (pp. 19). Forschungsinstitut für Mathematikdidaktik.

Lederman, N. G., Kuerbis, P., Loving, C., Ramey-Gassert, L., Roychoudhury, A., \& Spector, B. S. (1997). Professional knowledge standards for science teacher educators. Journal of Science Teacher Education, 8, 233-240. https://doi.org/10.1023/A:1017189315539.

Lin, F.-L., \& Cooney, T. (Eds.). (2001). Making sense of mathematics teacher education. Kluwer. 
Llinares, S., \& Krainer, K. (2006). Mathematics (student) teachers and teacher educators as learners. In A. Gutiérrez \& P. Boero (Eds.), Handbook of research on the psychology of mathematics education. Past, present and future (pp. 429-459). Sense Publishers.

Lloyd, G. M., de Carle, A., \& Coon-Kitt, M. J. (2021). When you're with me, I'm learning: A duoethnography of teacher educators' identities in relation to observing preservice teachers' emergent mathematics instruction. International Journal of Science and Mathematics Education, 19(Suppl. 1). https://doi.org/ 10.1007/s10763-021-10162-5.

Loucks-Horsley, S., Hewson, P. W., Love, N., \& Stiles, K. E. (1998). Designing professional development for teachers of science and mathematics. Corwin Press.

Loughran, J. (2014). Professionally developing as a teacher educator. Journal of Teacher Education, 65(4), 271-283. https://doi.org/10.1177/0022487114533386.

Maaß, K., Törner, G., Wernisch, D., Schäfer, E., \& Reitz-Koncebovski, K. (Eds.). (2015). Educating the educators: International approaches to scaling-up professional development in mathematics and science education. WTM-Verlag.

Maßß, K., Cobb, P., Krainer, K., \& Potari, D. (2019). Different ways to large scale implementation of innovative teaching approaches. Educational Studies in Mathematics, 102(3), 303-318. https://doi.org/10. 1007/s10649-019-09920-8.

McDonald, M., Kazemi, E., \& Kavanagh, S. S. (2013). Core practices and pedagogies of teacher education: A call for a common language and collective activity. Journal of Teacher Education, 64(5), 378-386.

McGatha, M. B., \& Rigelman, N. R. (2017). Elementary mathematics specialists: Developing, refining, examining programs that support mathematics teaching and learning. Information Age Publishing.

Munby, H., \& Russell, T. (1994). The authority of experience in learning to teach: Messages from a physics methods class. Journal of Teacher Education, 45(2), 86-95. https://doi.org/10.1177/ 0022487194045002002.

NCTM. (1989). Curriculum and evaluation standards for school mathematics. National Council of Teachers of Mathematics.

Peter-Koop, A., Begg, A., Breen, C., \& Santos-Wagner, V. (Eds.). (2003). Collaboration in teacher education. Examples from the context of mathematics education. Kluwer.

Robutti, O., Cusi, A., Clark-Wilson, A., Jaworski, B., Chapman, O., Esteley, C., Goos, M., Isoda, M., \& Joubert, M. (2016). ICME international survey on teachers working and learning through collaboration: June 2016. ZDM - The International Journal on Mathematics Education, 48(5), 651-690. https://doi.org/ 10.1007/s11858-016-0797-5.

Russell, T. (1995). Returning to the physics classroom to re-think how one learns to teach physics. In T. Russell \& F. Korthagen (Eds.), Teachers who teach teachers: Reflections on teacher education (pp. 95109). Falmer Press.

Schön, D. A. (1983). The reflective practitioner: How professionals think in action. Temple Smith.

Schuck, S., \& Brandenburg, R. (2020). Self-study in mathematics teacher education. In J. Kitchen, A. Berry, S. M. Bullock, A. R. Crowe, M. Taylor, H. Guðjónsdóttir, \& L. Thomas (Eds.), International handbook of self-study of teaching and teacher education practices (pp. 869-897). Springer. https://doi.org/10.1007/ 978-981-13-6880-6.

Sfard, A. (2005). What could be more practical than good research? On mutual relations between research and practice of mathematics education. Educational Studies in Mathematics, 58(3), 393-413. https://doi.org/ 10.1007/s10649-005-4818-5.

Shulman, L. S. (1986). Those who understand: Knowledge growth in teaching. Educational Researcher, 15(2), 4-14. https://doi.org/10.3102/0013189X015002004.

Smith, D. C. (2000). Content and pedagogical content knowledge for elementary science teacher educators: Knowing our students. Journal of Science Teacher Education, 11(1), 27-46. https://doi.org/10.1023/A: 1009471630989.

Stein, M. K., Smith, M. S., \& Silver, E. A. (1999). The development of professional developers: Learning to assist teachers in new settings in new ways. Harvard Educational Review, 69(3), 237-269. https://doi.org/ 10.17763/haer.69.3.h2267130727v6878.

Strässer, R., Brandell, G., Grevholm, B., \& Helenius, O. (2004). Educating for the future. Proceedings of an international research symposium on mathematics teachers education. NCM, Goeteborg University.

Superfine, A. C., \& Pitvorec, K. (2021). Using community artifacts to support novice math teacher educators in teaching prospective teachers. International Journal of Science and Mathematics Education, 19(Suppl. 1). https://doi.org/10.1007/s10763-021-10152-7.

Tatto, M. T., Lerman, S., \& Novotná, J. (2010). The organization of the mathematics preparation and development of teachers: A report from the ICMI Study 15. Journal of Mathematics Teacher Education, 13(4), 313-324. https://doi.org/10.1007/s10857-009-9139-7. 
Triantafillou, C., Psycharis, G., Potari, D., Bakogianni, D., \& Spiliotopoulou, V. (2021). Teacher educators' activity aiming to support inquiry through mathematics and science teacher collaboration. International Journal of Science and Mathematics Education, 19(Suppl. 1). https://doi.org/10.1007/s10763-021-101536.

Tzur, R. (2001). Becoming a mathematics teacher-educator: Conceptualizing the terrain through self-reflective analysis. Journal of Mathematics Teacher Education, 4(4), 259-283. https://doi.org/10.1023/A: 1013314009952.

Venkat, H., \& Askew, M. (2021). Development in South African primary mathematics teacher educators' work with in-service teachers. International Journal of Science and Mathematics Education, 19(Suppl. 1). https://doi.org/10.1007/s10763-021-10161-6.

Weinberg, A. E., Balgopal, M. M., \& Sample McMeeking, L. B. (2021). Professional growth and identity development of STEM teacher educators in a community of practice. International Journal of Science and Mathematics Education, 19(Suppl. 1). https://doi.org/10.1007/s10763-020-10148-9.

Willke, H. (2005). Systemtheorie II: Interventionstheorie. Lucius \& Lucius UTB.

Windschitl, M., Thompson, J., Braaten, M., \& Stroupe, D. (2012). Proposing a core set of instructional practices and tools for teachers of science. Science Education, 96, 878-903. https://doi.org/10.1002/sce. 21027.

Wood, T., Sullivan, P., Tirosh, D., Krainer, K., \& Jaworski, B. (Eds.). (2008). First international handbook of mathematics teacher education. 4 volumes. Sense Publishers.

Zehetmeier, S., Rösken-Winter, B., Potari, D., \& Ribeiro, M. (2017). Proceedings of the Third ERME Topic Conference on Mathematics Teaching, Resources and Teacher Professional Development (ETC3, October 5 to 7, 2016). https://hal.archives-ouvertes.fr/ETC3

\section{Affiliations}

\section{Konrad Krainer ${ }^{1} \cdot$ Ruhama Even $^{2} \cdot$ Meredith Park Rogers $^{3} \cdot$ Amanda Berry $^{4}$}

\section{Ruhama Even}

ruhama.even@weizmann.ac.il

Amanda Berry

amanda.berry@monash.edu

1 University of Klagenfurt, Klagenfurt, Austria

2 Weizmann Institute of Science, Rehovot, Israel

3 Indiana University, Bloomington, IN, USA

4 Monash University, Clayton, Australia 